\title{
Sahiplenmeden Tüketemez miyiz? Dijital Paylaşım Ekonomisinde Kiralama Üzerine Kavramsal Bir İnceleme*
}

\begin{tabular}{ll} 
dol & $\begin{array}{r}\text { Hakan KİRACI } \\
\text { Ruşen AKDEMIR }\end{array}$ \\
\hline$\ddot{O} \mathbf{z}$ & RS** $^{* *}$
\end{tabular}

Asırlardır süren ve satın almanın yüceltildiği klasik ticari yaşamda, başlarda oldukça dar kapsaml görülen kiralama seçeneğinin son yıllarda satın almanın karşısında giderek gelişim gösterdiği gözlemlenmektedir. Geçici yarar sunmasl, mülkiyet hakkının verilmemesi, kimi ürün/hizmetlerde satın almaya görece pahalı bir seçenek olarak kalması vb. sakıncalarının yanı sıra, satın almayla karşılaştırıldı̆̆ında önemli üstünlükler sağlayan kiralama hem kiraya veren hem de kiralayan kişi / kuruluşlar açısından cazip bir seçenek haline gelmektedir. Ayrıca dijital girişimlerin geleneksel pazaryerlerine üstünlük kurmasının da etkisiyle birey ya da kuruluşların "satın alma kirala" sloganına uyarak gereksinim ve isteklerini giderme tercihlerini / davranışlarını dönüş̧ürdü̈̆̈̈ görülmektedir. Bu çalışmada, satın almayla karş̧laştırma yapılarak kiralama davranışl ve dijital kiralama sistemleri incelenmekte; herhangi bir varlığın mülkiyetini elinde bulundurma durumunda söz konusu olan kullanma ve sunulan yararlardan faydalanmanın ekonomik alternatifi olarak kabul gören kiralama seçeneğinin dünü, bugünü ve yarını hakkında bilgiler verilmektedir. Diğer bir deyişle, literatür taramasıyla kiralama konusunda yapılan akademik çalışmaların bulguları derlenerek, Türkiye'de "bugün" için oldukça dar kapsamlı görülen kiralama seçeneğinin gelecekte yaygınlaştırılması için paydaşlara çeşitli öneriler getirilmektedir.

Anahtar Kelimeler: Kiralama, satın alma, dijital girişimcilik, paylaşım sistemleri.

\section{Can't We Consume Without Ownership? A Conceptual Research on Renting in the Digital Sharing Economy}

\begin{abstract}
In the classical commercial life, which has lasted for centuries and where the purchase has been glorified, the rental option, which was initially seen to be very narrow, has been observed to have progressively improved. Moreover, it could be said that renting has some disadvantages such as providing temporary benefits, non-granting of property rights, being a relatively expensive option to purchase in some products / services. However, the renting is becoming an attractive option which provides significant advantages compared to the purchasing, in terms of both the lessor and lessee person / organizations. In addition, it is seen that individuals or organizations are transforming their preferences / behaviors to fulfill their needs and desires by obeying the slogan called "rent, don't buy" with the effect of digital enterprises' superiority over traditional marketplaces. In this study, renting behavior and digital renting systems are briefly reviewed by comparing with purchasing and described the past, present and future of the renting option, which is considered to be an economic alternative to the use and benefits offered in case of the possession of any asset. In other words, by compiling the findings of academic studies on renting through literature review, various suggestions are made to the stakeholders in order to spread the renting option which is seen as very narrow for today in Turkey.
\end{abstract}

Keywords: Renting, purchasing, digital entrepreneurship, sharing systems.

\footnotetext{
${ }^{*}$ Bu çalışma, Bodrum/Muğla'da 17-20 Ekim 2019 tarihleri arasında "IV. International Entrepreneurship, Employment and Career Congress" kongrede bildiri olarak sunulmuş çalışmanın güncellenmiş ve genişletilmiş halidir.

** ORCID Doç. Dr., Muğla Sitkı Koçman Üniversitesi Fethiye İşletme Fakültesi, hakan.kiraci@yahoo.com

*** ORCID Arş. Gör., Muğla Sitkı Koçman Üniversitesi, Fethiye İşletme Fakültesi, rusenakdemir@hotmail.com
} 


\section{Extended Abstract}

While the ownership economy, which stands upright against the renting, go to seed day after day, the renting economy continues to increase. On the other hand, this shift toward renting in Turkey stands out yet not fully observed under the influence of financial, technological and social variables. In fact, although there are well-established housing rental and car rental markets in Turkey at the moment, time is needed for the formation of rental markets for products and services other than cars and housing. In Turkey, it is observed that rental options are not yet considered as an alternative consumption pattern by consumers in many product and service classifications such as durable home appliances, small hand tools, computer hardware / software.

Rental actions that have been carried out in traditional marketplaces for centuries have been replaced by digital rental platforms with the development of Internet technologies. Although traditional renting is still done, the rate of the renting activities with the support of virtual matching platforms (P2P) is rapidly increasing. On the other hand, analyzing the attitudes of the enterprises concerning the renting systems where they are the providers and the $\mathrm{P} 2 \mathrm{P}$ type systems that can be rented between individuals can provide important clues for the future of renting. When $\mathrm{P} 2 \mathrm{P}$ platforms are analyzed from the perspective of the provider, it is seen as a source of income in exchange for temporarily using any asset that remains unused in a corner.

Is the wedding dress (bridal) bought or rented? While the answer to this question was "bought - if it is too hard, it could be rented" in the middle of the previous century, it is now accepted that renting a wedding dress is a voluntary choice. It is a taboo in Turkey left behind many years of renting wedding dresses but many product / service groups in the same taboos lasts for the moment. At this point, the basic question is asked: Can't we consume without owning?: This article examines the economic / technological changes and the desire to use new products without paying a high price that led to renting increase that occurs on an individual scale.

Following the digital transformation in the late century, renting has become a rising trend. There are many factors leading the renting trend. Short employment contracts, shrinking families, lifestyles representing flexible lives, environmental awareness are some of those. For example, the fact that environmental problems are noticed by almost everyone ensures the increase in the rental trend. At this point, if we concentrate and ask the following question "is renting really an action that takes action with the motive of sustainability?" If the answer to this question will be asked for Turkey, any one would probably give a negative answer.

First of all, by comparing cost-benefit of two alternative consumption patterns, consumer's buyingrenting dilemma is examined in this study. Although the two alternative preferences undoubtedly differ from each other in terms of consumption processes, it should not be overlooked that they are acts of substitution for the other. 


\section{Giriş}

Kiralamanın karşısında duran sahiplik ekonomisi gün geçtikçe kan kaybederken, kiralama ekonomisi yükseliş eğilimini sürdürmektedir. Diğer taraftan finansal, teknolojik ve toplumsal değişkenlerin etkisiyle satın alma seçeneğinden kiralama seçeneğine doğru yaşanan bu kaymanın henüz Türkiye'de tam olarak gözlenemediği göze çarpmaktadır. Aslında Türkiye'de şu an için iyi işleyen konut kiralama ve araç kiralama piyasalarının bulunmasına karşın, otomobil ve konut dışındaki diğer ürün ve hizmetler için de kiralama pazarlarının oluşması için zamana ihtiyaç duyulmaktadır. Söz gelimi dayanıklı ev aletleri, küçük el aletleri, bilgisayar donanımı/ yazılımı gibi pek çok ürün ve hizmet sınıfında kiralama seçeneklerinin henüz tüketiciler tarafından yeterince "bir alternatif" olarak değerlendirilmediği ve mülkiyet aktarımı olmaksızın gerçekleştirilen bir tüketim kalıbının henüz tüketiciler tarafından pek dikkate alınmadığı gözlenmektedir. Buna karşın, dünya genelinde özellikle ortak tüketim malları bakımından, mülkiyet dışı tüketim kalıpları (kiralama / erişim) sunan hizmetlere talepte son zamanlarda hızlı bir artış olduğu görülmektedir (Moeller ve Wittkowski, 2010: 176).

Gelinlik satın alınır mı, kiralanır mı? Bu sorunun cevabı önceki yüzyılın ortalarında "satın alınır-çok zorda kalınırsa kiralanabilir" iken, günümüzde gelinlik kiralamanın gönüllü bir tercih olduğu artık kabul edilmektedir. Gelinlik kiralamanın tabu olduğu yıllar geride kalmış ve bu ürün özelinde epey yol kat edilmiş olabilir ancak pek çok ürün/hizmet grubunda aynı tabular şu an için sürmektedir. Bu noktada şu temel soru sorulmaktadır: Sahip olmadan tüketemez miyiz?

Bu makale, yüksek fiyatlı (premium) ve yeni ürünleri yüksek bedel ödemeden kullanma isteğinde artışla oluşan bireysel ölçekte kiralama eğilimine yol açan toplumsal, ekonomik ve teknolojik değişiklikleri incelemektedir. Her ne kadar çoğunlukla bir ürünü satın almak tek edinme şekli olarak kabul edilse de sonuçta satın alma ve kiralama, tüketicilerin alternatif ürün / hizmet edinme yöntemleri olarak görülmelidir (Moore ve Taylor, 2009: 1211).

\section{Neden Kiralama Trendi?}

McCracken'e (1988) göre dünya tüketim tarihinde iki temel evre vardır: Orta Çağ'da tüketimin anlamı bir nesnenin birinin ailesinde ne kadar süre kaldığına bağlı (örneğin beş nesilden uzun bir süredir ailede olmasıyla sahibine statü kazandırması) iken; sonraki Endüstri Çağında, yeni moda ve ev eşyalarına sahip olan ilk kişi olarak yeni eşyalara sahip olmakla daha kısa sürede statü kazanıldı. Bir sonraki (kısa süreliğine olsa da) statü kazanmada tüketim türü pekâlâ kiralama olabilir (Durgee ve O'Connor, 1995:102).

Geçtiğimiz yüzyılın sonlarında yaşanan dijital dönüşüm sonrasında, kiralama yükselen bir trend haline gelmiştir. Kiralama eğilimine yol açan pek çok etken bulunmaktadır. Kiralamaya yol açan toplumsal etkenlere gecikmiş evlilikler, daha fazla ebeveyn hanesinin olması (boşanmalar) ve daha fazla bekâr hanelerinin olması örnek olarak verilebilmektedir (Hargreaves, 2002: 14). Konut kiralama özelinde ise, işgücü piyasasında ve toplumsal yaşamda yaşanan değişimler (Knight ve Eakin (1997), süreklilik, konut fiyatlarının değerlenmesi ve konut kredisi faiz oranları (Hargreaves, 2002: 5), esnek yaşamların olması - söz gelimi kısa iş sözleşmeleriyle çalışma yaşamında yer alan bireylerin sürekli iş değiştirmeleri beraberinde işyerlerine yakın konumlarda yaşam sürme isteği - kiralamayı arttıran gelişmeler olarak karşımıza çıkmaktadır. Bu bağlamda, sık sık hareket eden insanlar, sahip olma ile ilgili yüksek işlem maliyetlerinin genellikle yüksek olmasından ötürü kiralamayı tercih etmektedirler (Hargreaves, 2002: 5). Öte yandan, küresel ya da ulusal finansal krizler ve sürekli yükselen çevre bilinci kiralama sektörünün temel itici güçleri arasında sayılmaktadır. 
Çevre sorunlarının hemen herkes tarafından fark edilmesi, kiralama trendinin yükselişini sağlamaktadır. Nitekim kiralamayla, ilk edinme finansmanı, risk alma (eskime ve arıza için) ve depolama gibi belirli pazarlama işlevlerinin (örneğin onarım) tüketiciden satıcılara geri kaydırılmasıyla birlikte ürünlerin ömürlerinin uzaması ve çevresel sorunların en aza indirilebilmesi mümkündür (Durgee ve O'Connor, 1995:102; Obenberger ve Brown, 1976: 82). $\mathrm{Bu}$ nokta durup "kiralama gerçekten sürdürülebilirlik güdüsüyle mi harekete geçen bir eylemdir?" sorusu sorulduğunda, Türkiye ölçeğinde bu soruya kolayca "muhtemelen değil" yanitı verilebilmektedir.

Gelecek kuşakların yaşam biçimine uygun bir tüketim kalıbı olarak nitelendirilen kiralama eyleminin (Durgee ve O’Connor, 1995:102) çevre bilinci ve tüketim karşıtlığı güdüsüyle yapılmasına ilişkin şöyle bir diyalog örnek olarak sunulabilmektedir:

- Sadece 100 dolara Wal-Mart'ta gerçekten güzel bir yemek masası vardl. Ancak sadece altı ay boyunca burada olacağımı için, kiralama yerinden kiraladık.

- Ancak kiralama daha pahalı değil mi? (Bence) kiralamak yerine, Wal-Mart'tan satın almaliydin.

- Ne, sadece altı aylı̆̆ına mı satın alacaktım? Yok hayır. Daha pahalı olmasına rağmen kiralamak için ödeme yapmayı tercih ederim, çünkü ona sadece altı aylığına ihtiyacımız vardı. (Moore ve Taylor, 2009: 1211)

Diyalogda da sözü edildiği üzere; kiralama eyleminin finansal güdülerin (zaten bilinen) yanı sıra, çevre bilinci ve tüketim karşıtlığının etkisiyle de gerçekleşebilmesi mümkündür. Kiralamaya yol açan gelişme ve etkenlerin yanı sıra, kiralamayı engelleyen etkenlere de kısaca değinilmesinde yarar vardır. Söz gelimi, olumsuz karşılıklılık korkusu, işlemin yüksek katılımlı olması, ürünlere sınırlı erişim ve P2P kiralama sitelerinin esnek olmama doğası, kiralama eylemlerini engelleyici faktörler arasında yer almaktadır (Heather, Ozanne ve Ballantine, 2015:1310). Ayrıca asırlardır süren sahipliğe dayalı edinme yönteminin yaşattığı mülkiyet gururunun (Durgee ve O'Connor, 1995:91) kiralamada hissedilememesi ve algilanan riskler, bireyleri kiralamadan uzaklaştıran bireysel ve toplumsal etkenlerin başında gelmektedir.

\section{Satın Alma - Kiralama İkilemi}

Bu çalışmada, tüketicilerin bir ürünü/hizmeti satın alıp almama ikilemi bir tarafa; satın alma ya da kiralama ikilemi de yaşayabileceğinden hareketle satın alma - kiralama tercihlerinin fayda/maliyet karşılaştırması yapılmaktadır. İki alternatif tercih kuşkusuz birbirlerinden tüketim süreçleri bakımından farklılıklar gösterse de diğerinin yerine geçebilecek (ikame) birer eylem oldukları gözden kaçırılmamalıdır. Sahiplik, bir kişi ile "sahip olma" adı verilen bir nesne arasındaki özel ilişkiyi belirtir ve nesneye "kişisel mülkiyet" veya "sahip olma" yüklenir (Snare, 1978:200). Nesne-benlik ilişkisi ve bu ilişkiyi düzenleyen kurallar bakımından sahiplik ve sahiplik aktarımının gerçekleşmediği işlemler (kiralama/erişim) birbirinden farklılaşmaktadır (Bardhi ve Eckhardt, 2012:882).

Satın almada bir ürün satıcıdan alıcıya taşınıp, para alıcıdan satıcıya gidip işlem tamamlanırken; bir kiralamada, bir ürün sağlayıcıdan kiracıya, para ise kiracıdan sağlayıcıya gider ve ardından ürün sağlayıcıya geri döner. Sonuçta, kiralayan yalnızca kiraladığı ürünün sağladığı işlevden yararlanır (Durgee ve O'Connor, 1995:91). Her ne kadar iki seçenek arasındaki finansal göstergeler karşılaştırılarak analiz yapılsa da son tahlilde kira / satın alma kararı genellikle "yaşam tarzı" ve mülkiyeti destekleyen kültürel mirasımızla ilgili finansal olmayan düşünceler tarafindan şekillenmektedir (Hargreaves, 2002: 15). 
Tablo 1: Satın Alma - Kiralama Karşılaştırması

\begin{tabular}{|c|c|}
\hline Satın Almada Özellikler & Kiralamada Özellikler \\
\hline Giderek güç kaybeden bir seçenek & Giderek güç kazanan bir seçenek \\
\hline Mülkiyet desteği sunar ve mülkiyeti vurgular & Esnek yaşam vaat eder ve kullanımı vurgular \\
\hline $\begin{array}{l}\text { Uzun süreli ürün kullanımında ekonomik seçenektir } \\
\text { (tasarruf sağlar) }\end{array}$ & $\begin{array}{l}\text { Kısa süreli ürün kullanımında ekonomik seçenektir } \\
\text { (tasarruf sağlar) }\end{array}$ \\
\hline $\begin{array}{l}\text { Kalıcı edinme yöntemiyle ürün güvence altına alınır ama } \\
\text { depolama zahmeti üstlenilir }\end{array}$ & $\begin{array}{l}\text { Geçici edinme yöntemiyle ürün güvence altına alınamaz } \\
\text { ama depolama zahmetinden kurtulmuş olur }\end{array}$ \\
\hline Geleneksel tüketici davranışını ifade eder & Politik tüketici davranışını ifade eder \\
\hline Toplum genelinde (görece) yüceltilen bir seçenek & Toplum genelinde (görece) küçümsenen bir seçenek \\
\hline Kesinlik ve eşitlik duygusu vardır & Kesinlik ve eşitlik duygusu yoktur \\
\hline $\begin{array}{l}\text { Daha az karar verme frekansı ve görece daha zor karar } \\
\text { süreci }\end{array}$ & Daha çok karar verme frekansı ve görece daha kolay karar \\
\hline $\begin{array}{l}\text { Görece yüksek tutarlı ödeme, harcamalar daha az } \\
\text { öngörülebilir ve görece daha çok değişken }\end{array}$ & $\begin{array}{l}\text { Görece düşük tutarlı ödeme, harcamalar daha öngörülebilir } \\
\text { ve görece daha az değişken }\end{array}$ \\
\hline $\begin{array}{l}\text { Geçici erişim aracılığıyla "yenilikleri” deneme / } \\
\text { deneyimleme olanağı sunulmaması }\end{array}$ & $\begin{array}{l}\text { Geçici erişim aracılığıyla olası satın alma kararı öncesinde } \\
\text { "yenilikleri" deneme/deneyimleme olanağ varlığı }\end{array}$ \\
\hline Finansal kayıptan kaçınma güdüsü daha az etkin & Finansal kayıptan kaçınma güdüsü daha etkin \\
\hline Ağırlıklı olarak işletmelerden edinme & Ağırlıklı olarak bireylerden edinme \\
\hline
\end{tabular}

Kaynak: (Kahneman ve Tversky, 1979; İrani ve Ramanathan, 1994; Durgee ve O’Connor, 1995; Choudhary vd., 1998; Varian, 2000; Hargreaves, 2002; Ozanne ve Ozanne, 2011; Lamberton ve Rose, 2012; Heather vd., 2015)'deki bilgiler 1ş1ğında oluşturulmuştur.

Tablo 1'de satın alma ve kiralama seçenekleri karşılaştırmalı olarak sunulmaktadır. Satın alma / kiralama karşılaştırması yapıldığında, her iki alternatif edinme yönteminin de üstün yönleri bulunmaktadır. Söz gelimi, satın almada söz konusu olan mülkiyet değişimi, kesinlik ve eşitlik duygusunun kiralamada bulunmaması, kiralama yerine satın alma kararının verilmesiyle kullanılacak bir ürünün tamamen güvence altına alınması ve satın almayla bir kez karar vererek uzun süre kullanılacak ürün edinilmiş olması satın almanın üstünlüğünü vurgulamaktadır (Durgee ve O’Connor, 1995:91). Diğer taraftan; satın alma seçeneğinde, bir defalığına olmakla beraber kiralama bedeline göre oldukça yüksek tutarlı bir ödeme yapılması (İrani ve Ramanathan, 1994:1), harcama tutarı dikkate alındığında genel olarak satın alma kararlarının tüketiciler açısından refah kaybı olarak nitelendirilmesi (Choudhary, Tomak ve Chaturvedi, 1998: 279), dayanıklı olan herhangi bir ürünün yalnızca bir kez kullanılması durumunda sahiplik durumunun net faydasının kiralamanın net faydasından büyük olmaması (Varian, 2000: 486), daha geçici yaşam tarzlarına yönelik trendlerde satın almanın yerinin giderek azalması, kalıcı etkisi olan ve satın almadan doğabilecek uyuşmazlıkların önlenmesi ve (kiralayarak) geçici satın alma yoluyla satın alınmadan önce kiralama yapılarak bir bakıma deneme olanağı sunulması (Ozanne ve Ozanne, 2011), kiralamada zihinsel muhasebe yaparak kazanç elde etme düşüncesinin var olması (Thaler, 1985), kayıptan kaçınma güdüsünün kiralamada daha etkin olması (Kahneman ve Tversky, 1979), kiralamanın (görece düşük bir bedel ödeyerek) yenilikleri deneyimleme olanağını sunması (Heather, Ozanne ve Ballantine, 2015:1324), satın almaya göre kiralama kararının kolaylık sağlaması (Heather, Ozanne ve 
Ballantine, 2015:1326), kiralama yapılarak satın almada söz konusu olan depolama zahmetinden kurtulması (Lamberton ve Rose, 2012), ilgili nakit harcamalarının genellikle sahip olma ile ilişkilendirilenden daha öngörülebilir ve daha az değişken olması (İrani ve Ramanathan, 1994: 14) satın almaya göre kiralamanın üstün olduğu yönleri yansıtmaktadır.

Satın alma / kiralama ikileminde, kimi zaman satın almanın yüceltilerek kiralamanın aşağılandığı ve kiralayanların küçümsendiği değerlendirmeler yapılabilmektedir. Bu bağlamda, kiralama ve kiralayan konusunda toplumda yerleşik ön yargılara da değinmekte yarar vardır. Söz gelimi, kiralanan ürün/hizmetlerin müşteri taleplerini karşılamada oldukça yetersiz kalacak seçenekler olarak değerlendirilmesi oldukça yanlıştır. Nitekim, kiralamaya konu olan ürünler moda, teknoloji ve fiyat düzeyi açısından kimi zaman oldukça yüksek olabilmektedir (Durgee ve O’Connor, 1995: 90). Ayrıca, kiralama kararı yalnızca finansal yetersizlik sonucu verilen bir karar ya da zorunluluk olarak görülmemelidir. Diğer taraftan, kiracıların sıklıkla kusurlu tüketiciler olarak görülmesi de (Heather, Ozanne ve Ballantine, 2015:1311) oldukça yanlış bir toplumsal algıyı yansıtmaktadır. Son olarak, toplumumuzda görülen ödünç alışverişinin makul karşılandığ 1 ancak kiralamanın olumsuz çağrışımlara yol açması durumu pek çok kültürde benzer bir tepki olarak gün yüzüne çıkmaktadır. Nitekim, ABD'de gece elbisesi kiralayan butiklerin ürünlerin üzerine "kiralık" yazmak yerine "ödünç" yazması dikkat çekicidir (Durgee ve O'Connor, 1995:91). Bununla birlikte, dijital kiralama platformlarının isimlerinde de ödünç (borrow) sözcügünün, kimi zaman kiralama (renting) yerine kullanıldığı görülebilmektedir.

Satın alma - kiralama ikileminde "kullanım süresine" ayrıca yer verilmesinde yarar vardır. Çünkü kullanım süresi tüketicilerin edinme yöntemini (satın alma / kiralama) önemli ölçüde etkilemektedir. Şöyle ki; süre kısaldığında, kiralama tercih edilmekteyken; daha uzun süreler için, her iki seçeneğin de ekonomik sonuçları aynı olsa bile satın alma tercih edilmektedir (Moore ve Taylor, 2009: 1211). Bir öğenin kiralanması, bir öğenin kısa süreli kullanımıyla uyumlu olarak algılanırken; öğenin satın alınması, daha uzun süreli kullanım için ayrılan daha kalıcı bir edinme yöntemi olarak algılanmaktadır (Moore ve Taylor, 2009: 1211). $\mathrm{Bu}$ noktadan hareketle, ekonomik ömrünün en fazla yarısı kadarlık süreye kadar kiralama, yarısından fazla sürelerde ise satın almanın öne geçtiği düşünülmektedir (Choudhary, Tomak ve Chaturvedi, 1998: 277). Diğer bir deyişle, bir malın tüketildiği zaman aralığı önemlidir çünkü eğer bu süre bozulabilir mallar için olduğu kadar kısaysa kiralanması uygun değildir (Choudhary, Tomak ve Chaturvedi, 1998: 279). Diğer taraftan, kullanılan ürünün elde tutma süresi uzadıkça kiralamanın maliyeti yükselmekte, satın alma seçeneğinin maliyeti ise düşmektedir. $\mathrm{Bu}$ noktadan hareketle, çok uzun kullanılması düşünülmeyen ürünlerde hemen her zaman kiralamanın satın alma seçeneğine göre üstün olduğunu ifade etmekte yarar vardır.

\section{Kiralama ve Diğer Alternatif Tüketim Modellerinin Karşılaştırması}

Uzun süredir ihmal edilmiş bir şekilde kullanmadan elimizde bulundurduğumuz varlıklarımız neler? Bu varlıkları geçici olarak elden çıkararak nasıl kazanç elde edebiliriz? Tümüyle elden çıkarmayı düşündüğümüzde bedelsiz bağış ya da belirli bir bedel üzerinden ikinci el pazaryerlerinde satış ilk akla gelen çözümlerdir. Diğer taraftan, birer tüketici olarak, satın almak yerine kiralamak ya da ödünç almak vb. alternatif tüketim modelleri sergilenebilmektedir. Bu bağlamda, satın alma / kiralama karşılaştırmasının yanı sıra alternatif tüm edinme yöntemleri ile kiralama modelinin karşılaştırmasının yapılması yerinde olacaktır. Tablo 2'de belirli kriterler açısından bu karşılaştırma gözler önüne serilmiştir. Bu karşılaştırmada mülkiyet devri olmaması ve belirli bir bedel üzerinden değişim eyleminin yapılıyor olması kiralamanın temel nitelikleri olarak göze çarpmaktadır. 
Tüketici davranışı konusundaki literatüre göz atıldığında, geçici edinim yöntemlerinin (kiralama, ödünç alma vb.) genellikle tüketici davranışının bir yönü olarak göz ardı edildiği, araştırmaların çoğunun daimî edinim üzerinde yoğunlaştığı anlaşılmaktadır (Albinsson ve Perera, 2012: 306). Aslında, tüketici davranışının geçici edinim yönünün detaylı incelemesinin ve çarpıcı tespitlerin yapılması, gelecek nesillerin alternatif tüketim kalıbı olarak nitelendirilen kiralama hakkında gerekli bilgilerin gün yüzüne çıkarılmasını sağlayacaktır. Benzer şekilde Lovelock ve Gummesson'a (2004) göre, alıcı - satıcı arasındaki mülkiyet devri içeren değişim ilişkisinin yanı sıra mülkiyet devri içermeyen değişimlerin (kiralama/erişim/ödünç) incelenmesinin "pazar faaliyetlerinin görüntülenmesinde ve hizmet gerçekliğinin yeni ve farklı boyutlarını ortaya çıkarmada yepyeni bir mercek" sunduğu dile getirilmektedir.

Tablo 2: Alternatif Tüketim Modellerinin Karşıllaştırılması

\begin{tabular}{|l|c|c|c|}
\hline \multicolumn{1}{|c|}{ Davranış } & Sahiplik / Erişim & Karşılıklılık & Bedel Ödeme \\
\hline Kiralama & Erişim & Var & Parasal \\
\hline \multicolumn{2}{|c|}{ Erişim } & Yok & Yok \\
\hline Ödünç Alma/Verme & Mülkiyet transferi & Yok & Yok \\
\hline Bağış Yapma & Mülkiyet transferi & Var & Parasal Olmayan \\
\hline Takas Yapma & Mülkiyet transferi & Var & Parasal \\
\hline İkinci Eı Ürün Satın Alma & Mülkiyet transferi & Var & Parasal \\
\hline Geleneksel Tüketim Davranışı & &
\end{tabular}

Kaynak: Roos ve Hahn, 2017:115’ten uyarlanmıştır.

Satın alma, kiralama, ödünç alma, bağış alma ve takas yapma gibi alternatif edinme yolları düşünüldüğünde; kiralama eyleminde, kiralama bedeli karşılığında ticari bir eylem yapılıyor olması ile hayırseverlik olarak nitelendirilebilen ticari olmayan edinme yöntemlerinden (ödünç alma, bağış alma, takas yapma) açıkça ayrılmaktadır. Söz gelimi ödünç alışverişi ile kiralamanın benzer ve farklı yönlerine göz atmak gerekirse; ödünç alışverişi ile kiralama mülkiyet devrinin olmaması bakımından birbirine benzerken, bu iki davranış arasındaki temel farklar ödünç alışverişinde doğrudan bir bedel ödemesi olmaması ve daha az kişisel olan kiralamanın aksine ödünç alışverişinin genellikle sürmekte olan dostluk ilişkisinin bir parçası olmasıdır (Durgee ve O’Connor, 1995:91).

\section{Kiralama Kavramı}

Kiralama, bir tarafın diğer tarafa para karşılığında belirli bir süre kullanım teklif ettiği ve mülkiyetinde değişiklik olmadığı bir işlem olarak tanımlanmaktadır (Durgee ve O'Connor, 1995:90). Bir başka tanıma göre, kiralama; kiralayanın varlığı ile kira bedelinin değişiminin yapıldığı bir takas eylemi olarak da değerlendirilmektedir (Heather, Ozanne ve Ballantine, 2015:1311). Diğer taraftan, kiralamanın bilişim sektöründe karşılığı erişimdir. Söz gelimi diğer fiziksel ürünlerden farklı olarak, kopyalanması oldukça kolay olan ve telif hakkı yasalarının uygulanmasında büyük sorunların yaşandığı yazılımlarda (Choudhary, Tomak ve Chaturvedi, 1998: 277) yeni teknolojilerin de yardımıyla talep eden bireylere sınırlandırılmış bir süre ile yazılımın kullandırılabilmesi erişim olarak kavramsallaştırılmaktadır. Bu yönüyle kiralama 
sektörü, ürün sunumundan hizmet sunumuna dönüşü temsil etmektedir. Bu bağlamda; kitap, dergi, bilgisayar yazılımı, müzik ve video gibi bilgi malları kopyalanabilir, paylaşılabilir, yeniden satılabilir veya kiralanabilir (Varian, 2000: 473). Nitekim, video, kitap, müzik ve yazılım gibi bilgi ürünleri kopyalanıp paylaşılabildiği, yeniden satılabildiği ve kiralanabildiği için, tüketicilerin bunlara erişebilmeleri için artan bir dizi seçenek mevcuttur (Knox ve Eliashberg, 2009: 126).

Finansal kiralama (leasing) ile kısa süreli kiralama birbirinden farklıdır (Lovelock ve Gummesson, 2004). Yine, tüketicilerin hem sağlayıcı (kiraya veren) hem de yararlanıc1 (kiralayan) olarak yer aldığı P2P türü etkileşim, dijital kiralama platformlarını işletmeden tüketiciye (B2C) kiralamanın yapıldığı diğer pazaryerlerinden ayırmaktadır.

Kiralama kavramına değindikten sonra bu konudaki literatüre göz atılmasında yarar vardır. Kiralama konusunda yapılan bilimsel araştırmaların önemli bir kısmında, bireylerin kiralama tercihlerini belirleyen etkenler ortaya konmaktadır. En başta akla gelen finansal temelli ekonomik yarar elde etme düşüncesinin yanı sıra, çok sayıda etkenin bireylerin kiralama tercihleri üzerinde önemli etkileri bulunmaktadır. Yine de P2P türü kiralama platformlarının katılımcıları, geçici tasarruf ve (satın almayarak) çevreyi koruma ve atıkları azaltma için bir yol sağladığı gerçeğini övmesine karşın, ekonomik fayda hala erişim temelli tüketimi inceleyen diğer araştırmalarla tutarlı olarak, P2P kiralamadaki katılımcılar için birincil öneme sahip olmaktadır (Heather, Ozanne ve Ballantine, 2015:1324). Ayrıca, kiralama güdüleri sağlayıcı (kiraya veren) yönünden incelendiğinde, sağlayıcılar temel olarak ekonomik kaygılarla güdülenmekte, gelirlerini en üst düzeye çıkarmak için sahip oldukları varlık kalemlerini sık sık kiralamayı tercih etmekte; bununla beraber bazı sağlayıcılar P2P kiralamayı, genelleştirilmiş karşlıklılık ve özgeci davranış için bir firsat (ortam) olarak görmektedirler (Heather, Ozanne ve Ballantine, 2015:1324).

Moeller ve Wittkowski (2010) tarafindan Alman kullanıcıların yer aldığ bir kiralama platformunun 461 üyesi üzerinde yapılan çalışma ile kiralama niyetini belirleyen altı faktör incelenmiştir. Araştırma sonucunda, mülkiyet dışı hizmetlere olan talebin "sahiplenme öneminden" (bir tüketicinin tam sahipliğe verdiği önem) negatif yönde; “eğilim yönelimi” ve "uygunluk" yöneliminden pozitif yönde etkilendiği ortaya çıkmıştır. Bir başka deyişle, kiralamada söz konusu olan sahipsizliğin, "sahipliğin önemi" bakımından eksik, tüketicilerin eğilim ve rahatllğı açısından olumlu yönde etkilendiği bulunmuştur. Durgee ve O'Connor (1995), birey-nesne ilişkisinin, nesne kiralandığında değiştirildiğini ileri sürmekte, ancak ihtiyaç geçici olduğunda tercih edilen yüksek ilgilenimli bir davranış olduğunu belirtmektedir. Araç kiralama üzerine Trocchia ve Beatty (2003) tarafindan yapılan çalışmada çeşitlilik arzusu, basitleştirilmiş bakım ve sosyal onay isteğinin kiralama davranışı üzerinde etkili olan motivasyon faktörleri olduğu öne sürülmektedir.

Heather, Ozanne ve Ballantine (2015) tarafindan yapılan bir araştırmanın katılımcıları, kiralama yoluyla tüketimlerini gerçekleştirmelerini değerleriyle tutarlı, daha sürdürülebilir, tüketim karşıtı bir yaşam biçimi sunduğunu belirtmişlerdir. Diğer taraftan, tüketim karşıtllğ̆ açısından kiralamaya bakıldığında, çok sayıda kiralamanın da tüketimi arttıran bir eylem haline gelebilmesi olasıdır (Heather, Ozanne ve Ballantine, 2015:1326). Ayrıca, her ne kadar paylaşım ekonomisi kapsamında değerlendirilen yeni nesil kiralama platformları ile çevrecilik motivasyonları eşleştirilse de (Lawson, 2011), kiralama davranışının çevrecilik güdüsü ile iliş̧isinin olmadığını yansıtan çalışmalar da mevcuttur (Moeller ve Wittkowski, 2010).

Literatürde “Amerikan Rüyası” olarak anılan konut sahipliği (Beracha ve Johnson, 2012: 217) ile kiralamanın fayda/maliyet karşılaştırmasının yapıldığı pek çok araştırma bulunmaktadır. Söz gelimi Krueckeberg (1999), konut sektöründeki kiralamaya karşı tarihsel 
önyargıları incelediği çalışmasında, mülk sahiplerinin kiracılardan daha iyi birer yurttaş olarak görüldüğü sömürgecilik dönemleriyle başlayan Amerikan kamu politikasını incelemekte ve "kiracıları damgalayan kamu politikasının diğer toplumsal cinsiyet, ırk, din ve milliyet yanlılıkları kadar tehlikeli bir önyargı" olduğunu ileri sürmektedir (Krueckeberg, 1999: 9).

Knox ve Eliashberg (2009) tarafından yeni ve kullanılmış ev videolarını kiralayan ve satan bir perakende satış noktasının perspektifinin ve iş modelinin incelendiği bir araştırmada, fiyatlama stratejilerinin bireylerin satın alma / kiralama tercihlerini belirlediği öne sürülmekte ve kiralama için daha düşük bir fiyat ödeme eğiliminde olan müşterilerin (toplu alım yoluyla) kiralama yerine satın alma eğiliminin daha yüksek olduğu belirlenmektedir. Bu nedenle, hem yeni hem de daha önce görüntülenen başlıkları kiralayan ve satan bir satıcı için en uygun fiyat ve müşteri bölümlendirmesinin yapılması önem kazanmaktadır.

Kiralama / satın alma ikileminde, tüketicinin değerlendirme kriteri olarak yer alan "kullanım süresinin uzunluğu" yapılan bilimsel araştırmalarda da önemli bir odak noktası olmuştur. Moore ve Taylor (2009) tarafından 58 kişi üzerinde yapılan bir araştırma sonucunda mobilya kısa bir süre kullanılacaksa, satın alma yerine kiralamanın tercih edildiği, daha uzun bir süre için ise satın alma seçeneğinin tercih edildiği ortaya çıkmıştır. Üstelik bu tercihler modeli, iki edinme yöntemi boyunca diğer bütün faktörlerin -harcayacakları para miktarının, varlığın kalitesinin, varlığın kurtarma değerinin- sabit tutulduğu gerçeği göz önüne alındığında oldukça çarpıcıdır (Moore ve Taylor, 2009: 1212). Benzer şekilde Hirst vd. (1994), tüketicilerin malları, malların kullanım süresine karşılık gelen kredilerle finanse ettiğini dile getirmektedir. Böyle bir durumda, o ürünü kira sözleşmesine benzer bir şekilde satın aldığı ortaya çıkmaktadır. $\mathrm{Bu}$ nedenle, insanlar, zararları kazançlar ile entegre etmeyi kolaylaştırmak için maliyet ve faydaların zamanlamasını uyumlaştırmaya çalışırlar (Moore ve Taylor, 2009: 1211). Bu noktadan hareketle, Voicu ve Seiler (2013) ve Beracha ve Johnson (2012) örnek bir süre boyunca kiralamanın mülkiyete karşın tercih üstünlüğü olduğunu ileri sürmektedirler. Çok uzak olmayan bir gelecekte, ürünlerin o kadar karmaşık hale geldiği tamamen kiralık bir yaşam tarzı, tüketicilerin onları bulundurma ve koruma sorumluluğunu almak yerine, onları kiralamak isteyeceği bir dünya oluşturacağı hayal edilebilir (Durgee ve O’Connor, 1995: 90).

\section{Dijital Kiralama Platformları}

Yüzyıllardır geleneksel pazaryerlerinde sürdürülen kiralama eylemleri, internet teknolojilerinin gelişmesiyle birlikte yerini dijital kiralama platformlarına bırakmıştır. Halen geleneksel kiralama yapılmakla birlikte, sanal eşleştirici platformlar (P2P) yardımıyla yapılan kiralama eylemlerinin ağırlığı günden güne artmaktadır. Nitekim, P2P sistem aracılığılla, kiralamak istemesine karşın gerekli deneyim ve uzmanlığa sahip olmadığı için çekinceleri olan sağlayıcılara, kendi adlarına kiralama eyleminin üstlenilmesi söz konusu olmaktadır (Heather, Ozanne ve Ballantine, 2015:1326).

Genel olarak kiralamanın giderek daha popüler hale gelmesine karşın, P2P türü kiralama hakkında çok az şey bilinmektedir (Heather, Ozanne ve Ballantine, 2015:1310). İşletmelerin sağlayıcı olarak yer aldığı kiralama sistemlerine ve bireyler arası kiralama yapılabilen P2P türü sistemlere yönelik tutumlarının çözümlenmesi, kiralamanın geleceğine ilişkin önemli ipuçları sağlayabilecektir. Kişiler arası kiralama (P2P), kiracıların (mülk devri olmaksızın) geçici olarak mallara (belirli bir erişim/kira bedeli karşılığında) erişmelerini sağlayan, aynı zamanda mülklerini (fiziksel sahipliğini) ve geçici olarak elden çıkarma yeteneğini kiralayanlara sağlayan bir erişim şeklidir (Heather, Ozanne ve Ballantine, 2015:1310). P2P platformları sağlayıcı yönünden incelendiğinde, bir köşede kullanılmadan öylece duran herhangi bir varlığın geçici olarak bir bireye kullandırılması karşılığında kazanç elde etme kapısı olarak 
görülmektedir. Diğer taraftan literatürde, kiralama ve diğer paylaşım ağları, ürün kullanım yoğunluğunu artırarak daha sürdürülebilir tüketmenin bir yolu olarak ürün servis sistemleri (PSS) çatısı altında incelenmektedir (Heather, Ozanne ve Ballantine, 2015:1311). Ürün servis sistemleri ise (PSS), "rekabetçi olmak, müşterileri memnun etmek ve geleneksel iş modellerinden daha çevreye duyarlı olmak için geliştirilen bir ürün, hizmet, aktör ağı ve destekleyici altyapı sistemi” olarak tanımlanmaktadır (Mont, 2001: 239). Teorik olarak yönlendirilen tematik analiz, P2P kiralamanın, geniş bir ortak yaratma, piyasa aracılı değişimi ve bir toplum arzusundan kaynaklanan, politik tüketicilikten esinlenen kısa vadeli / aralıklı işlemleri içeren bir self servis değişimi olarak tanımlandığını yansıtmaktadır (Heather, Ozanne ve Ballantine, 2015:1310).

Ekonomik açıdan bir ürünü satın almak yerine çok sayıda ürünü sayısız kiralamaya olanak sağlayan kiralama platformları, bireysel tüketicilere hem çok sayıda ürün seçeneği hem de önemli yararlar sunmaktadır. Bu bağlamda, bir varlık satın alıp almama kararı, sınırsız tüketim için sabit bir ücret ödemenin veya her tüketim için ayrı bir ödeme yapılması kararı gibi günlük yaşamda sıkça karşılaşılan daha genel kararlar seti özelliklerini taşımaktadır (Knox ve Eliashberg, 2009: 127). Sınırsız kullanım için sabit bir ödeme yapılması, üyelik yapılarak erişim sağlanması, kullanım başına ödeme (kullandığın kadar öde) alınması şeklinde belirlenen çeşitli ödeme seçeneklerinin sunulmasına karşın, bir kuruluş yerine kendi gibi bir tüketiciden çevrimiçi kiralama gibi bir eyleminin gerçekten uygun bir tüketim biçimi olup olmadığı (bu şekilde algılanıp algılanmadığı) önemli bir soru olarak karşımıza çıkmaktadır (Moeller ve Wittkowski, 2010: 181). Diğer taraftan, aylık sabit ödeme istense de tüketicilerin bu iş modeline karşı bir önyargı taşıdığını söylemek yanlış olmayacaktır (Lambrecht ve Skiera, 2006). Üstelik, her ne kadar katılımcılar P2P kiralamasına katılırken kendi kişisel faydalarını artırmayı düşünse de kiralama platformları aracılığıyla ortaklaşa (kolektif) fayda yaratılması da söz konusu olmaktadır (Heather, Ozanne ve Ballantine, 2015:1324).

Tablo 3: Kiralama Platformu Örnekleri

\begin{tabular}{|l|l|}
\hline Hizmet Grubu & Sunulan Dijital Platform \\
\hline Kitap kiralama & $\begin{array}{l}\text { Chegg, Bookdepository, Student2Student, Text Books Rentals, Booklender, } \\
\text { Campusbooks }\end{array}$ \\
\hline Araç kiralama & Zipcar, Sidecar, carnextdoor, car2go \\
\hline Giyim/aksesuar kiralama & CaaStle, Fashionhire, Hurr Collective, Bagborrowsteal \\
\hline Bahçe kiralama & Landshare, Campinmygarden \\
\hline Otomobil park yeri kiralama & JustPark, Parkatmyhouse, Haystack \\
\hline Bisiklet kiralama & Spinlister, Citibike \\
\hline Özel Gün/Gece Giysileri & GirlMeetDress, rentredcarpet, elbisekirala, dressistanbul \\
\hline El Çantası Kiralama & Rent the Runway, Bag Romance, The Hand Bag Rental, Bag Butler \\
\hline Genel & Neighborgoods, Bumerangla \\
\hline Kısa süreli ev kiralama & Vrbo, AirBnb, Home Away, Hemenkiralık \\
\hline Oyuncak kiralama & Toy Box Tots, Rent That Toy, Rent-A-Toy \\
\hline Uzman kiralama & Bionluk, uzmankirala \\
\hline Çalışan (personel) kiralama & Taskrabbit, Fiverr, Zaarly \\
\hline
\end{tabular}

Günümüzde pek çok ürün kategorisinde kiralama yapılmasına olanak sağlayan dijital kiralama platformları Tablo 3 'te özet olarak sunulmuştur. Sayıları binlerle ifade edilen dijital platformlardan sadece birkaçının yansıtılabildiği bu tablo, kiralama eylemlerinde sanal ortamın ne denli tetikleyici rol üstlendiğini gözler önüne sermektedir. Tabloda yer alan her bir kiralama platformunu açıklamak yerine bu satırlarda yalnızca "Bumerangla" isimli ulusal ölçekli kiralama platformundan bahsedilecektir. Bu topraklardan bir girişim olarak; günlük yaşam / spor / deneyime yönelik araç-gerecin kiralanabildiği Bumerangla, katılımcılarına kiralama 
yaparak yaşamın tadını çıkarmaya davet etmektedir. Fotoğraf makinesi, oyun konsolu, spor araç-gereci gibi çok sayıda seçeneği kullanıcılarına sunan bu dijital platform, yalnızca kiralama bedelinin ödenerek belirli bir süre kullanım hakkı vermektedir. Sınırlı süre kullanılacak ve bu sürenin dışında sahip olmanın yük olarak hissedilebileceği tamir ekipmanı, bavul, bisiklet, kamp ekipmanı, her türlü kask ve elbette uçangöz (drone) gibi seçenekler bu platformdaki sunulan ürünlerden yalnızca bir bölümüdür. Bumerangla'nın "daha az satın al, daha yeşil bir dünyada yaşa" sloganına uyarak bu platformun kullanıcısı olmayı kabul eden katılımcılar, hem çevreci bir tüketim kalıbı sergilemekte hem de yakın gelecekte yaşanacak olası bir satın alma kararı öncesi ürün deneme olanağı elde etmektedirler.

Tablo 3'te yansitılan dijital kiralama platformlarının, bireylerin satın almaktan kiralamaya kaymalarını kolaylaştırmak için çözmeleri gereken önemli sorunlar vardır. Öncelikle (sağlayıcı) bireyleri paylaşım platformlarından bir şeyleri kiralamaya, ya da elindeki varlıkları paylaşım platformunda listelemeye özendirici eylemler yapması gerekmektedir. Ayrıca (yararlanıcı) bireylerin kiralamayı tercih etmeleri üzerinde engelleyici etkileri bulunan güven ve mülkiyete bağımlılık gibi etkenlerin olumsuz etkilerinin en aza indirilmesi için çaba gösterilmelidir. Söz gelimi, güven konusunda sunulacak güvenceler oldukça önem taşımaktadır. Bu güvencelerden biri olan sigorta, her iki taraf için riski azalttığından, kiracının kaza sonucu hasar ödemekten endişe duyması gerekmediğinden ve sağlayıcı artık kırılmış bir ürünün değiştirilmesi konusunda endişelenmek zorunda kalmaması nedeniyle, P2P kiralama siteleri her zaman sigorta seçenekleri sunmalıdır (Heather, Ozanne ve Ballantine, 2015:13251326). Ayrıca, güven sağlamanın başka bir yolu da kullanıcıları, ürünleri ve web sitesinin kendisini markalamaktır (Heather, Ozanne ve Ballantine, 2015:1326). Bu bağlamda, AirBnb platformundaki "Süper evsahibi" rozeti gibi, kiralama platformlarının gelen yorum, eleştiri, şikayetler sonucunda sağlayıcılar ve yararlanıcılar için bir derecelendirmeye gitmeleri yerinde olabilecektir.

Etkileşimin dijital ortamda yapılması, dijital kiralamada güven faktörünün irdelenmesini beraberinde getirmektedir. Bu platformların kullanıcılarının, alışılmış mülkiyeti terk edip kiralamaya yönelmesi için güven bunalımı oluşturacak olası durumların ayrıca düşünülmesi gerekmektedir. Çünkü bu tür platformlarda yabancılar arasındaki güven, daha fazla sorgulanması gereken bir alandır (Heather, Ozanne ve Ballantine, 2015:1326). Ayrica, bu dijital platformları özellikle ilk kez kullanacak kullanıcıların "ilkleri" yaşamadaki tedirginlikleri ve tüm katılımcıların bu platformları kullanmada algıladıkları riskler ancak sunulan güvencelerle en aza indirilebilmektedir. Söz gelimi, kiralayan kullanıcının "hatalı kullanımı" karşısında kiraya veren kullanıcının olası zararlarının tazmin edebilmesi ve tarafsız bir şekilde her iki tarafın haklarını korumak için gerekli tedbirler alınması oldukça önemlidir.

Gelir modeli doğru kurgulanmayan ya da yetersiz müşteri talebi ile karşılaşan dijital kiralama platformlarının faaliyetlerine son vermesi mümkün olabiliyor. Bu nedenle, güven faktörünün yanı sıra, dijital kiralama platformlarının üzerinde durması gereken başka konular da bulunmaktadır. İlk olarak, sağlayıcı / yararlanıcı sayıları dengeli olmalıdır. Bir kiralama platformunda sayıları yüzlerle ifade edilen kiraya veren türü kullanıcılara karşılık, sayıları binlerle hatta on binlerle ifade edilen kiralamak isteyen kullanıcı sayılarının varlığ platformunda henüz denge sağlanamadığını ve bu dengenin sağlanamaması durumunda faaliyetlerine son verebileceğini yansıtmaktadır. Dijital ikinci el platformlarından örnek vermek gerekirse, hem çok sayıda ikinci el ürün alan hem de çok sayıda ikinci el satan kullanıcının yer aldığı platformlar faaliyetlerini aralıksız bir biçimde sürdürmektedir. İkinci olarak, kiralama platformunun tanıtımının iyi yapılması gerekmektedir. Kuşkusuz kiralamanın bireye sunduğu ekonomik yararların yanı sıra, yapılacak tanıtımda tüketim karşıtlığı, ortaklaşa yaşam ve çevrecilik vurguları yapılarak toplumsal tatmin ve sürdürülebilirlik arayışında olan bireylere 
mesaj verilmesi söz konusu olacaktır. Tanıtım eylemlerinde öncelikli amaç dijital kiralama platformunun adını duyurmak görünse de temel amaç platformun kullanıcı sayısını hızlı bir biçimde arttırabilmektir. Bu noktada, potansiyel kullanıcıları dijital kiralama platformu kullanıcısı haline getirmek için kiralama eylemine "eğlence" faktörünün unsurları entegre edilmelidir. Ayrıca platformun üyelerinin üyeliklerini sürdürmeleri için katılımcı sadakat uygulamaları yapılması da gerekmektedir. Üçüncü olarak; bireyleri dijital kiralama platformuna yöneltebilecek güdüleyici faktörleri belirlemesi gerekmektedir. Dördüncü olarak, dijital kiralama platformunun bir web sitesi ya da mobil sürüm/uygulama olduğundan hareketle, sanal kiralama ortamında gerekli görsel teknolojiler iyi kurgulanması gerekmektedir. Kiralanan objelerin çözünürlükleri, farklı açılardan görünümleri, fotoğrafın yanı sıra kısa tanıtım videolarının bulunabilmesi, farklı ödeme türlerinin kullanıcılara sunulması, sipariş sürecinin her bir aşamasının sadeleştirilmesi vb. gibi önlemler dijital kiralama platformlarının başarılı olmasını sağlayacak unsurlardır. Söz gelimi, çözünürlük konusunda ikinci el pazar yerleri iyi izlenmelidir. Dijital kiralama platformları için, dijital ikinci el pazar yerleri başarı örneği olarak görüldüğünden bu platformlardan örnek vermek gerekirse; Shen, Chiou ve Kuo (2011) tarafından eBay (ikinci el ürün satışı) platformu konusunda yapılan bir araştırma sonucunda yüksek çözünürlüklü fotoğraflara sahip ilanların satışın gerçekleştirilmesi üzerinde oldukça önemli etkilerde bulunduğu belirlenmiştir.

Buraya kadar sıralanan konuların dışında, iş modelinin ve gelir modelinin doğru kurgulanmas1, ürün/hizmet çeşitliliği ve kiralama süresi çeşitliliğinin sağlanması, sürekli yenilenmiş bir vitrinle kullanıcıların karşılanması gibi konularda dijital kiralama platformlarına önemli görevler düşmektedir.

\section{Kiralama Trendi ve İşletmeler}

Makalenin başında sözü edilen satın alma-kiralama mücadelesinde, kiralamanın güç kazanmasının işletmeler üzerindeki olası etkilerine kısaca değinmekte yarar vardır. İlk olarak, kiralama pazarlarının ticari yaşama yerleşmesiyle birlikte, önceki yüzyılda pek çok monopol piyasaya yeni üreticilerin sunum yapmalarıyla, üreticilerin kârlarında yaşanan düşüşün benzerinin yaşanması beklenmektedir. Bir başka deyişle, kiralama trendinin yaygınlaşması ve tüketicilerin önemli bir bölümünün bu tüketim biçimine yönelmesi ile birlikte satın alma modeline dayalı işlerini yürüten işletmelerin satışlarında olası düşüşler yaşanabilecektir. Diğer taraftan, kiralama sistemleri ile işletmelerin kârlarının artabilmesi de söz konusudur. Paylaşım işlemlerinin marjinal üretim maliyetinden düşük olması durumunda, içerik yalnızca birkaç kez görüntülendiğinde ve işlem maliyetlerinin düşük olması durumunda ve bir paylaşım piyasası, yüksek değerli ve düşük değerli kullanıcıları bölümlendirmek için bir yol sağladığında, bu yeni sistemle birlikte var olan işletmelerin kârları düşmek bir yana arttırabilmeleri mümkündür (Varian, 2000: 473).

İkinci olarak, kiralama, işletmelerin mevcut ürünlerine yeni pazarlar yaratması anlamına gelmektedir. $\mathrm{Bu}$ durumda "varlıklı" tüketicinin satın alabildiğini "varlıklı olmayan" tüketicilere kiralanmasıyla işletmelerin toplam gelirleri arttırılabilir (Varian, 2000: 486). Bununla birlikte, farklılaştırılmış ürün stratejisi ile satışa sunulacak ve kiralanacak ürünlerin farklılaştırması yapılabilmektedir. Çünkü kiralanacak ürünler ile satın alınarak kullanılacak ürünlerin kalitesi ve dayanıklılığ farklı olabilmektedir. Söz gelimi kiralanmak üzere üretilmiş smokinler perakende satış noktalarında satışa sunulan smokinlerden (sık sık kuru temizlemelere dayanacak şekilde güçlü) farklı tasarlanmakta ve üretilmektedir (Durgee ve O'Connor, 1995:102). 
Üçüncü olarak, sağlayıcı işletmeden kiralama ve bireylerin kendi aralarında (P2P) ürün kiralamalarına olanak sağlayan kiralama platformları (sistemleri), pazara yoğun dağıtımı yapılması planlanan bir ürün için hem ön talep ölçümü sağlamakta hem de düşük tutarlı ödeme yaparak kiralama yapılarak çok sayıda tüketiciye ulaşılmasını sağlamaktadır. Örneğin San Francisco'daki elektrikli araç üreticisinin geçtiğimiz aylarda lansmanını yaptığı Nissan Scoot Quad'ın yüksek bir bedelle satılması yerine kısa süreliğine (7 saate kadar) kiralanması tercih edilmiştir. Bu şekilde, elektrikli araç sürme deneyiminin çok daha fazla tüketiciyle buluşması sağlanmıştır.

Dördüncü olarak, satın alma-kiralama ikilemini birbirine destek olup güçlendiren iki yapı olarak düşünerek, tüketicilere her ikisinden izler taşıyan değer önerilerinin sunulması söz konusu olabilecektir. Hem tüketicilerin sahip oldukları varlıklarını geçici elden çıkarma (örneğin kiralama) yöntemleri yerine daha çok tamamen elden çıkarma (örneğin ikinci el ürün satışı) seçeneklerine yoğunlaşmaları (Heather, Ozanne ve Ballantine, 2015:1311) hem de malların kiralanmasının giderek daha popüler bir tüketim şekli olmasına karşın, tüketiciler hala mülkiyete değer vermesi nedeniyle dijital kiralama platformları (dijital işletmeler) müşterilerine "sahip olma" ve "sahiplik dışı" tüketim biçimlerinin bir karışımını teklif etmeyi düşünmelidir (Moeller ve Wittkowski, 2010: 176). Yine de tüketicilerin mülkiyete alışmış olmaları ve davranışlarını değiştirmekte tereddüt etmeleri nedeniyle yeni müşteri bulma konusunda zorluklar yaşanmaktadır (Heather, Ozanne ve Ballantine, 2015:1311). Söz gelimi, Türkiye'de faaliyete geçen ve çok sayıda deneyim ürününü kiralama olanağı sunan "bumerangla" isimli kiralama platformu talep yetersizliği nedeniyle faaliyetine son veren dijital kiralama platformları arasındaki yerini almıştır.

\section{Sonuç}

On sekizinci yüzyll İngiltere'sindeki kâr amaçlı kütüphaneler gibi, ödünç alışverişinin belirli bir bedel karşıllğında yapılması durumunda oluşan kiralama eylemi, satın alma türü tüketim modelindeki alıcıları bu tüketim türünde kiracılara dönüștürmektedir. Satın alma temelinde tüketici davranışlarını sergileyen tüketicilerin yeni nesil kiralama platformları ile kiralamaya yönelmesi, uzunca bir süredir konut sektöründe dile getirilen "neden satın alabilecekken kiralayasınız ki?" sorgulaması ve "paranızı kiraya harcamayın" klişesi (Beracha, Seiler ve Johnson, 2012: 71) bize satın almanın karşısında kiralamanın ne kadar önemsendiğini gözler önüne sermektedir. Bu noktadan hareketle, konaklayacağınız bir odayı bir gece kiralamak mı yoksa odayı otelle görüşüp tümüyle satın almak $\mathrm{m} ı$ istersiniz? Bu soru oldukça mantıksız gibi görünmekle birlikte, kiralama ve satın alma arasındaki ikilemi gözler önüne sermesi bakımından çarpıcıdır.

1991 yllında yaklaşı 13.000 kiralama merkezinin olduğu ABD ülkesi, geleneksel ürün kiralamada öncü konumda yer almıştır. Örneğin ev eşyaları ve ev aletleri kiralama üzerine ABD'de 1973 yılında kurulan ve 1990'a dek 400 şubeye ulaşan Rent-A-Center, kullanıcılarına çok sayıda seçenek sunmuştur. Kol saati, bavul, özel gün kostümleri (gece elbiseleri), her türlü dış giyim, çanta, mücevher, yazlık ev ve çok daha fazlasının satın alınması yerine geçici kullanımını öneren kiralamaya karşı tüketicilerin yaklaşımları geçmişte, günümüzde ve gelecekte farlılıklar göstermektedir. Durgee ve O'Connor (1995) ABD ülkesi özelinde 60'l1 yıllarla 90'lı yılları şöyle kıyaslamaktadır:

"Otuz yll önce, kiralık şeyler genellikle dairelerden, arabalardan ve kamyonlardan, aletlerden ve bazı spor malzemelerinden oluşmaktaydı. Şimdi ise kiralanmış ürünler arasında video kasetli filmler, kameralar, resimler (Dreyfus, 1983), resmi kayafetler (erkekler ve kadinlar için), kürkler, oyuncaklar, mobilyalar, yatlar, çocuk bezleri, depolama birimleri, uçaklar, tatil 
evleri, limuzinler, stereolar, aletleri, bitkiler, parti malzemeleri, eğlence araçları, müzik aletleri, jakuziler, egzersiz donanımları, tıbbi ekipman, mücevher ve diğer birçok dayanıklı tüketim mallarl sayllabilmektedir." (Durgee ve O'Connor, 1995: 89).

Önceleri geleneksel yöntemlerle yüz yüze iletişim kurularak yapılan kiralama eylemlerinin bulunduğumuz yüzyılda yerini daha çok dijital kiralama platformlarına bırakması ve bu platformlarda B2C türünün yanı sıra P2P türü etkileşim kurulmasına olanak sağlanması, kiralama sektörünün geleceğinin parlak olduğunu gözler önüne seren gelişmeler olarak karşımıza çıkmaktadır. Çevrimiçi (online) sosyal ağların ortaya çıkmasıyla birlikte kiralama uygulamalarının giderek gelişme ve çeşitlenme göstermesi karşısında bireylerin kiralamaya yaklaşımları da önemli ölçüde değişmektedir. Ayrıca, günümüz bireylerinin yaşam tarzındaki değişimler, tüketimde sahip olmama yaklaşımına ivme kazandırmaktadır (Moeller ve Wittkowski, 2010: 177).

Önceleri kişisel ekonomik yarar sağlama güdüsüyle yapılan kiralama eylemlerinde zamanla güdüleyici faktörlerde çeşitlendirmeler yaşanmıştır. Nitekim, değişiklik arayan, maceraperest, hareketli bir yaşama sahip olan kişilerde kiralamaya yönelmenin daha fazla olması beklenmektedir. Tüketici tercihlerinde mülkiyeti değil kullanımı vurgulayan kiralama eylem / uygulamalarının artması, dünya genelinde kiralama platformlarına her geçen gün yenilerinin eklenmesi ve bu tür platformların kullanıcılarının artması bir tarafta yer alırken, mülkiyet tarafının ağırlığı hala ön planda durmaktadır. Bu durum Türkiye özelinde mülkiyet tarafında çok daha fazla yoğunlaşma olduğunu göstermektedir.

Bireyin satın almayarak yaptı̆̆ her bir kiralama eylemi, insanoğlunun geleceğine $1 s ̧ 1 k$ tutan ekolojik bir tüketim eylemi olarak değerlendirilmektedir. Bir insanın bir günde içtiği birkaç litrelik suyu ve kişisel temizliği için kullandığı su miktarını bir kenarda tutarsak, her bir satın alma kararı bireylerin dolaylı su tüketimini doğrudan su tüketiminin kat kat üzerine çıkarmaktadır. Satın alma yerine kiralamaya daha çok bireyin yönelmesi ile, çevre sorunlarının bir nebze çözümüne dolaylı destek olunması anlamına gelmektedir. Ancak kuşkusuz, kiralama ekonomisinde ekolojik duyarlılık bireyleri güdüleyen faktörlerden yalnızca biridir.

Kiralama kavramını inceleyen bu makale sonucunda, günümüzde dar kapsamlı sürdürülen kiralamaya dayalı toplulukların küresel bir kiralama ekonomisine dönüşmesi için şunlar önerilmektedir:

- Dijital kiralama ekonomisinin gelişimi için, P2P türü kiralama platformlarına yönelik birey ve işletmelerin tutumların çözümlenmesi gerekmektedir. Özellikle bireyleri bu tüketim modeline yönelten ve bu tüketim modelinden kaçınmasına yol açan etkenlerin ortaya çıkarılması oldukça önemlidir.

- Kiralama platformlarında sağlayıcı yani kiraya veren konumunda yer alması beklenen kullanıcıların, ellerindeki varlıkları kiralama platformlarında listeleme konusunda özendirilmesi gerekmektedir.

- Kiralama platformlarında yararlanıcı yani kiralayan konumunda yer alması beklenen kullanıcılar için, kiralamanın önünde dimdik duran engelleyici faktörler olan güven ve mülkiyete bağımlılık vb. konularda neler yapılabileceği irdelenmelidir.

- Başarıyla yürütülen dijital kiralama platformlarının iş modelleri incelenerek, postmodern çağda başarının formüllerinin neler olabileceği gün yüzüne çıkarılmalıdır.

- Kiralama platformlarında yeni iş modelleri tasarlanmalıdır. Bu yenilikçilik eğilimi sayesinde; tüketicilere kiralama süresi bakımından, kiralama biçimi bakımından, ödeme yöntemi açısından, sunulan ürün çeşitliliği bakımından, sağlanana müşteri hizmetleri bakımından birbirinden farklılaşması sağlanabilecektir. Kiralama platformlarının "kiralamanın dayanılmaz hafifliği" başta olmak üzere yoğun tanıtım faaliyetleri 
sürdürmesi gerekmektedir. Başarılı tanıtım ve olumlu tüketici tepkileri ile kiralama ve kiralama platformlarının; ikinci el alışverişinde oluşan "Sahibinden", "Gittigidiyor" ve "Letgo" platform örnekleri gibi başarıyla sürdürülen birer kiralama platformu haline dönüşmesi mümkündür.

- Son olarak, dijital kiralamanın yasal zeminin hazırlanması ve kiralamada (birey ve işletmelere) vergi avantajı sağlanması, bu akıma kapılan kullanıcı sayısını arttırabilmesi olasidir.

\section{Kaynaklar}

Albinsson, P.A. ve Perera, B.Y. (2012). "Alternative Marketplaces in the 21st Century: Building Community Through Sharing Events", Journal of Consumer Behavior, 11(4): 303-315.

Bardhi, F. \& Eckhardt, G.M. (2012). "Access-Based Consumption: The Case of Car Sharing”, Journal of Consumer Research, 39 (4): 881-898.

Beracha, E. \& Johnson, K.H. (2012). "Lessons from Over 30 Years of Buy versus Rent Decisions: Is the American Dream Always Wise?", Real Estate Economics, 40 (2): 217 247.

Beracha, E., Seiler, M.J., \& Johnson, K.H. (2012). "The Rent Versus Buy Decision: Investigating the Needed Property Appreciation Rates to be Indifferent Between Renting and Buying Property", Journal of Real Estate Practice and Education, 15 (2): 71-88.

Choudhary, V., Tomak, K. \& Chaturvedi, A. (1998). "Economic Benefits of Renting Software", Journal of Organizational Computing and Electronic Commerce, 8 (4): 277-305, doi: 10.1207/s15327744joce0804_2 doi: $10.1108 / 0736376031 \overline{0456937}$

Durgee, J. F., \& O'Connor, G. C. (1995). “An Exploration into Renting as Consumption Behavior", Psychology \& Marketing, 12 (2): 89-104, doi:10.1002/mar.4220120202

Hargreaves, B. (2002). “To Rent or Buy; That is the Question”, Pacific Rim Real Estate Society (PRRES) Conference 2002, Christchurch, 21-23 Ocak.

Heather E. P., Ozanne, L.K. \& Ballantine, P.W. (2015). "Examining Temporary Disposition and Acquisition in Peer-to-Peer Renting", Journal of Marketing Management, (31)11-12: 1310-1332, doi: 10.1080/0267257X.2015.1013490

Hirst, D. E., Joyce, E. J. ve Schadewald, M. S. (1994). "Mental Accounting and Outcome Contingency in Consumer-Borrowing Decisions", Organizational Behavior and Human Decision Processes, 58 (1): 136-152.

Irani, S. ve Ramanathan, D. (1994). "The problem of renting versus buying", http://citeseerx.ist.psu.edu/viewdoc/download?doi=10.1.1.44.8179\&rep=rep1\&type $=$ pd f (Erişim: 04.05.2019).

Kahneman, D. ve Tversky, A. (1979). "Prospect Theory: An Analysis of Decision Under Risk", Econometrica, (47)1: 263-91.

Knight J.R. \& Eakin C.F. (1997), “A New Look at the Home Ownership Decision”, Real Estate Issues, 23 (2): 20-29.

Knox, G., \& Eliashberg, J. (2009). "The Consumer's Rent vs. Buy Decision in the Rentailer", International Journal of Research in Marketing, 26 (2): 125-135.

Lambrecht, A., \& Skiera, B. (2006). "Paying too much and Being Happy About it: Causes and Consequences of Tariff Choice-Biases", Journal of Marketing Research, 43(2), 212-223.

Lawson, S. J. (2011). "Forsaking ownership: Three Essays on Non-Ownership Consumption and Alternative Forms of Exchange", (yayınlanmamış doktora tezi), Florida State University, ABD. 
Lovelock, C., \& Gummesson, E. (2004). "Whither services marketing? In Search of a New Paradigm and Fresh Perspectives", Journal of Service Research, 7(1), 20-41, doi:10.1177/1094670504266131

McCracken, G. (1988). Culture and Consumption, Bloomington University Press.

Moeller, S., \& Wittkowski, K. (2010). "The Burdens of Ownership: Reasons for Preferring Renting", Managing Service Quality, 20 (2): 176-191, doi:10.1108/09604521011027598

Mont, O. (2001). "Introducing and Developing a Product-Service System (PSS) Concept in Sweden", Lund: International Institute for Environmental Economics.

Moore, A. \& Taylor, M. (2009). "Why Buy When You Can Rent? A Brief Investigation of Differences in Acquisition Mode Based on Duration", Applied Economics Letters, 16(12): 1211-1213. doi: 10.1080/13504850701367304

Obenberger, R. W. \& Brown, S. W. (1976). "A marketing Alternative: Consumer Leasing and Renting”, Business Horizons, 19(1): 82-86.

Ozanne, L. K., \& Ozanne, J. L. (2011). "A Child's Right to Play: The Social Construction of Civic Virtues in Toy Libraries”, Journal of Public Policy \& Marketing, 30 (2): 264-278. doi:10.1509/jppm.30.2.264

Roos, D. \& Hahn, R. (2017). Does Shared Consumption Affect Consumers' Values, Attitudes, and Norms? A Panel Study, Journal of Business Research, 77(1): 113-123.

Shen, C., Chiou, J., \& Kuo, B. (2011). "Remedies for Information Asymmetry in Online Transactions: An Investigation into the Impact of Web Page Signals on Auction Outcome", Internet Research, 21 (2): 154-170, doi:10.1108/10662241111123748

Snare, F. (1972). "The Concept of Property", American Philosophical Quarterly, 9 (2): 200206.

Thaler, R. H. (1985). "Mental Accounting and Consumer Choice", Marketing Science, (4) 3: $119-214$.

Trocchia, P., \& Beatty, S. (2003). “An Empirical Examination of Automobile Lease vs Finance Motivational Processes", Journal of Consumer Marketing, 20 (1): 28-43,

Varian, H.R. (2000). "Buying, Sharing and Renting Information Goods", The Journal of Industrial Economics, 48 (4): 473-488.

Voicu,C. \& Seiler, M.J. (2013). "Deriving the Rent Versus Buy Decision in theAbsence of Expected Home Price Appreciation or Risk Premia", Journal of Real Estate Finance and Economics, 22 (1): 33-38. 